\title{
A Coincidence of Interests: Prison Higher Education in Massachusetts \\ A. Jones
}

\section{INTRODUCTION}

Post-secondary education is flourishing in the prisons of Massachusetts. As late as 1967 not a single college course was available to prisoners for credit. Only twenty years later, seven institutions of higher learning offer programs of study in as many different facilities within the state. Two-year programs, some leading to the associate's degree, are offered by Middlesex, Mount Wachusetts, and Quinsigamoond Community Colleges and by the University of Massachusetts at Boston. Programs leading to the bachelor's degree are offered by Curry College, the University of Massachusetts at Amherst, and Boston University, which has also implemented one of the first in-prison master's degree programs in the United States. Cumulative annual enrollments now approach one thousand students (approximately ten percent of the state's prison population). In 1988 undergraduate and graduate degrees were earned by thirty-eight prisoners. It is clear that higher education has been received in the prisons of Massachusetts within the last two decades.

The timing of the proliferation of advanced education in the state's prisons poses important questions about the actual purposes of these programs. Notably, a look at the history of penological practices suggests that higher learning was embraced by the prison systems at precisely the same time that the reformation of offenders ceased to be a popular aim of incarceration. Moreover, the literature on prison education emphasizes the priority of value and moral education, decidedly reformative aims. How can we explain this apparent contradiction? Is it in fact the case that despite what educators have to say about their aims, ${ }^{1}$ reformation is not what prison authorities have in mind when they allow these programs to flourish? To what extent does the proliferation of post-secondary prison education represent a transfer within the system of the reformative function of punishment?

I am not suggesting that the growth of prison education in this state was the result of collusion between higher learning and the professional degraders (i.e., prison authorities). On the contrary, the relationship between higher learning and corrections in Massachusetts has been characterized by tension. The literature implies that this tension is a consequence of a fundamental conflict of values (Corcoran, 1975);

Ray Jones has been incarcerated for more than a decade. He recently received his doctoral degree from the University of Massachusetts (Amherst) where he presently teaches. 
however, the real cause may be far more pedestrian. Historical accounts of the prison reveal a continuous and enormous gulf between humanitarian language and barbarous reality. Throughout, the degraders have never opposed the ideal (or language) of education, only its actuality. Since higher learning in Massachusetts has actually dared to educate rather than simply mouth the myths of education to which the degraders were inured, one could expect that during the period when rehabilitation was under attack the prison education programs would have been the first to go; yet, as we have seen, the opposite is the case.

I suggest that prison higher education in the case of Massachusetts is more the product of an often contradictory and haphazard evolutionary process than a carefully implemented plan for meeting educational needs. My intention is to illuminate this process and its implications through an analysis of the role of education in the penal context; the circumstances which allowed higher learning to enter the prisons of Massachusetts; the expression of reformative theory in the articulation of program goals, objectives and curriculum; and finally, the interplay of theory, educational practice, and penal bureaucracy. The analysis presented is based on secondary sources drawn primarily from the literature of penology and primary sources consisting of interviews ${ }^{2}$ conducted with the founders and/or directors of three of the postsecondary prison eduction programs currently operating within the Massachusetts' prison system.

\section{THE PENAL CONTEXT}

\section{The Modern Prison and Soul Reformation}

The American prison and the modern concept of incarceration was introduced by Quakers with the opening of Philadelphia's Walnut Street Jail in 1790. Reformers such as Benjamin Rush of Philadelphia, inspired in part by the ideas of the eighteenth-century reforming jurists, sought an alternative to executions and other corporal punishments that they regarded as cruel and inhumane. That alternative would conform to what Menninger describes as the

...Quaker belief that a man who had done wrong, and had been convicted of it, must be brought to realize that he had done wrong, and desire to do better; he must become penitent before he could be helped (Menninger, 1969: 222).

Penitence would emerge from hard labor, education, and religious training interspersed with periods of contemplative isolation in a confinement that allowed intense surveillance and discipline.

The invention of the penitentiary marked not only the culmination of a shift in the nature of punishment, but also in its object and purpose. 
The object of punishment shifted from the body to the soul of the offender (Foucault, 1977). The criminal, in the spirit of the Enlightenment, would not be viewed as intractably evil. The nature of man was essentially good and the offending agent could be located in a corrupt or deficient soul. The purpose of punishment had moved from a public demonstration of monarchical power inflicted against an evil body to deployment of a new technology the prison - in which the coercive power of the new state would be utilized to effect a reformation of the soul that would simultaneously affirm the moral superiority of the avenging community and the intrinsic worth of all men.

The desire to effect transformation was among the original aims of incarceration and from the outset learning was presumed to have a role in the accomplishment of that aim (Angle, 1982; Reagan and Stoughton, 1976; Roberts, 1971). The logic of education's inclusion in the penal regime was relatively simple. In an homogeneous America law was not yet estranged from Protestant morality. The individual who violated the laws of civil community ipso facto revealed himself as a sinner against the laws of God. Education was comprised of Bible-based religious training and basic skills were taught to promote a literacy sufficient to enable Biblical study and contemplation in the isolation of the asylum.

While in the vision of the reformers education would teach men the Christian way of life, soul transformation remained subservient to the purely incapacitative and deterrent aims of punishment and the role of education was severely limited. Through the mid-nineteenth century few formal programs existed. The nation's first prison school, for example, opened at Walnut Street Jail in 1798, but operated only during prisoners' scant leisure hours and its 'curriculum' was devoted to basic skills and religious training. The same was true of the Boston Prison Discipline Society which, beginning in 1825, developed and promoted the concept of Sabbath Schools for religious training. Later it offered basic skills to combat the rampant illiteracy which hindered knowledge of the Bible (Angle, 1982; Roberts, 1971). Reagan and Stoughton observe:

Admittedly, these early attempts at reform to be obtained solely through the haphazard visitations by chaplains were doomed to failure; yet they did represent the first attempt at education in the form of isolated incidents which gradually began to establish a pattern. The assumption on the part of the prison chaplains that the Bible was the keynote of reform led to basic attempts at reading and writing in order that biblical truths could be effectively mastered and absorbed (Reagan and Stoughton, 1976: 36).

The pattern Reagan and Stoughton note may not have been the most important. The early reforms and their associated efforts evidenced a great gulf between theory and practice, between claims about the 
existence of education programs and the reality of what was actually offered. It is this pattern that would characterize the history of correctional education.

\section{'Scientific Penology' and Rehabilitation}

The late nineteenth century witnessed a second great shift in penological thought. Beginning with the introduction of the 'New' or 'Scientific' penology of the 1870s and culminating in the 'rehabilitative ideal' of the 1960s, the human sciences and the emerging professions (i.e., social work, hygiene, psychology), with their theories of criminal causation, attempted to achieve the reformation of a deviance which proved to be unresponsive to religiosity. Reformation would remain an aim of incarceration, but those who sought to achieve it would no longer seek to act upon the soul.

The new penology's initial exemplar was at the Elmira Reformatory in Elmira, New York (1876-1900). The Elmira Reformatory is reputed to have offered a penal regime consistent with the philosophy espoused by the National Congress on Penitentiary and Reformatory Discipline in 1870. It advised:

humanitarian, individualized treatment. Indeterminate sentencing, a carefully planned mark system, progressive classification, meaningful academic and industrial education, intense religious instruction, and positive reinforcement and mild discipline, as opposed to traditional 'brute force', were proposed as a means of increasing prisoners' opportunities, enhancing self-esteem and ultimately, fostering rehabilitation (Pisciotta, 1983).

Reagan and Stoughton describe the penal regime at Elmira as "an all encompassing manipulation of consciousness, from dawn to dusk" designed to "transform the mental, physical and moral habits" of Brockway's 'patients.' This new approach seems to have represented a direct response to the rampant abuses of the old model of the penitentiary, but there is reason to suspect that a new philosophy would have emerged regardless, since the reformation of the soul could not be sustained as a social aim of incarceration in an increasingly heterogeneous and secular society in which legal and moral order were already quite distinct.

Brockway is reputed to have given education an important place in the regime at Elmira (Roberts, 1971). Indeed, the reformatory was referred to as 'the college on the hill.'

Individual study was stressed and the 'inmate scholars' were required to work on the lessons by gaslight each night. The two-year program, based upon a ten-month academic year, was designed to provide the 'inmates' with rudimentary reading, spelling, and arithme- 
tic during the first year, and progress to history, geography, civil government and moral philosophy in the second (Pisciotta, 1983: 617).

Faculty and students from nearby Elmira Women's College instructed upper-level courses from the outset and a professor from that college, Dr. D.R. Ford, was placed in charge of the reformatory's educational efforts (Roberts, 1971).

Sources are available which provide overviews of specific educational programs 'developed' in American prisons (Angle, 1982; Reagan and Stoughton, 1976; Roberts, 1971) but, for our purposes, only the essence of that history is needed. Education at Elmira was secondary to discipline. As Pisciotta so accurately states: "The rhetoric of 'scientific reform' and humanitarian treatment changed the form but not the substance of control" (Pisciotta, 1983: 620). We must remember that Elmira was a 'model' of the humanitarian environment: an ideal to which other prisons across the nation would aspire but never reach. At Elmira, education was given a place in penological theory, but penological practice made that place as insignificant as possible. In prisons receiving less public attention, the gulf between theory and practice was likely to have been far wider.

\section{The Emergence of Higher Learning}

The Elmira experience represented the first instance of higher learning's involvement in American prisons. Yet its involvement did not give prisoners the opportunity to take accredited courses that might lead to a degree. Higher learning at Elmira took the form of weekly lectures on topics such as 'Honesty is the Best Policy' (Pisciotta, 1983). The lecturers may have been college professors, but the prisoners who attended were not regarded as college students. More than a half-century would pass before higher learning would make accredited courses and degree programs available to prisoners.

Higher learning, nationally and in Massachusetts, actually made sporadic attempts to implement structured programs in the prisons during the rehabilitative era. Among the early prison education programs cited by Roberts (1971) are ones offered by the University of Maryland at Maryland Penitentiary, 1953; the University of Kansas and St. Mary's College at Leavenworth, 1957; the University of Southern Illinois at the state prison in Menard in 1957; and correspondence courses at several federal penitentiaries. Most of these programs consisted of very sparse offerings and did not hold out the possibility of earning a degree. In 1967, at the height of the rehabilitative era, only about 3,000 prisoners, less than one percent of the total population, participated in some form of post-secondary education and most of these were involved in correspondence courses (Adams, 1968). 
This dismal picture is not surprising. From the advent of scientific penology through the rehabilitative era, prisons have been characterized by an internal conflict between reformative and punitive aims (Rothman, 1980:10). Treatment staff educated in deterministic theories of behavior saw the roots of criminality in antecedent causes for which the individual may not have been responsible, while security personnel viewed the offender as responsible for his deviance and deserving of punishment. Treatment and reformation were not only made subservient to security and punishment, they were co-opted by security and punishment. The educators, psychologists, and social workers accountable only to prison administrations sustained the mythology of treatment. The reformative aim was spoken about, but only the punitive aim was acted upon. In such an atmosphere, outsiders with sincere reformative intentions were seldom welcome.

\section{Higher Education Enters the Prisons of Massachusetts}

It was not until 1968 that higher learning entered the Massachusetts prison system. The Student-Tutor Evaluation Project (STEP) founded by Babbette Spiegel, began in Walpole State Prison and eventually expanded to Norfolk State Prison (Bryant, 1984). That program consisted of humanities courses certified by Northeastern University and taught by tutors. Its aim was limited to preparing men to pursue higher education once paroled or released. Babette Spiegel, who believed in the inherent good of education, was the first of many 'dedicated volunteers' who would shape higher learning in Massachusetts' prisons.

The rehabilitative era was very much alive at that time, but under attack from both ends of the political spectrum. The prison system, like other social institutions of that era, had come into the view of outside ideologues who attacked rehabilitative theory, and when some of these outsiders actually entered the prisons, they were confronted with the reality that many so-called rehabilitative programs were either ineffective or existed only in the 'mythology of corrections' (Germanotta, 1988; Bryant, 1988). The Massachusetts Department of Corrections, even in crisis, embraced higher learning reluctantly. It allowed Spiegel's program into the prison because she had political influence (Bryant, 1984), but it demonstrated its discomfort from the outset by restricting participation to fifteen carefully selected prisoners per session (Reagan and Stoughton, 1976).

\section{The New Arrangement}

The rehabilitative era came to an end in the early 1970s, collapsing under attacks from both liberals and conservatives. The latter viewed the emphasis on treatment programs, however mythological, as symp- 
tomatic of society's leniency toward criminal offenders. Liberals, increasingly cognizant of the gulf between the expressed aims of rehabilitation and the reality of imprisonment, rejected the notion of treatment as 'theoretically faulty,' 'systematically discriminatory,' and 'inconsistent with Justice' (American Friends Service Committee, 1971). What emerged in the United States were a variety of so-called 'justice models.' Whether developed by liberals or conservatives, each of the justice models shared some common characteristics. The most important of these was that the reformative aim would no longer dominate the language and theory of corrections. Treatment staff would still employ the familiar language of rehabilitation, but the real business of corrections would be the protection of public safety through the provision of care and custody. Bifurcation best describes a system of confinement in which 'voluntary programs' were made available to those prisoners who desired them, while the rest were simply incapacitated or 'warehoused.'

In Massachusetts, the transition in penal philosophy coincided with sustained violent uprisings within its prisons. The Omnibus Prison Reform Act (Chapter 777 of the Massachusetts General Laws) was enacted. Because it legislated such reforms as furloughs, education and work release, and the establishment of lesser-security facilities, many have regarded this legislation as a statement of rehabilitative intent. But, if its reforms responded to prisoners' violent expressions of despair and loss of hope, it also provided the logic for distinct facilities and varying levels of classification which became the hallmark of the new philosophy of incarceration. It offered more humane confinement in lower security facilities, while at the same time furnishing the logic of maximum-security wastelands barren of programs.

\section{Accidental' Praxis}

In these circumstances, ${ }^{3}$ with coercive reformation abandoned and rehabilitation no longer the responsibility of corrections, higher learning was able to enter the prisons as a separate force, able to shape a mission without wholly conforming to correctional hostility to rehabilitative programming. The educators who guided higher learning into the prisons were not at the time necessarily aware of or concerned with the fact that they acted at a pivotal moment in the history of the prison, nor did they typically concern themselves with stating broader purposes. Bryant notes:

It [higher education] hasn't been based upon a deliberate philosophy. From the very beginning ... it all started with these so-called dedicated volunteers, people who for one reason or another decided to come in and bring educational services to prisoners ... (Bryant, 1988). 
They themselves attribute the birth of the program they developed to a series of 'fascinating coincidences' (Bryant, 1984; 1988; Barker, 1988; Germanotta, 1988); indeed, the University of Massachusetts at Boston initiated the Higher Education in Prison Project (HEPP) at Norfolk due to a bizarre series of events. Spiegel's STEP program was administered by Brandeis University and staffed by Northeastern University. Two early STEP students released from prison and two female Brandeis students killed a Boston police officer during a robbery attempt. After the two universities abandoned the program as their response to adverse publicity, Spiegel was able to secure support from the University of Massachusetts, which acknowledged the need for such programs created by the educational provisions of Chapter 777. Given the educational backgrounds of most prisoners, preparatory work within the prisons would be required before students could take advantage of external opportunities while on education release. There was, however, another and less idealistic reason for the university's interest:

It hit that era when L.E.A.A. [Law Enforcement Assistance Administration] was involved; ... there was money available. When there's money available people go after it and develop programs to fit that need. The request at that time was for a liberalizing effect on prisons; there was a lot of money in L.E.A.A. for programs for juveniles, for education, for creative programming. U/Mass. Boston being a young, new school, went after it (Bryant, 1988).

One result of the bid to secure L.E.A.A. funding was that the program's goals and objectives had to be specific. In seeking to continue Spiegel's earlier efforts and deliver a preparatory program consisting of basic skills and humanities education, the U. Mass. Program stressed "the reformative or rehabilitative effects of education" (Bryant, 1988).

Elizabeth Barker, who founded Boston University's Prison Education Program, had no such intention when she first entered Norfolk Prison in 1972. She came as a result of a competition between the Boston University's Quiz Team and another comprised of prisoners. Although she was somewhat sensitive to prisoners' plight, she recalls sharing many of the common assumptions about prisoners and her astonishment at discovering "bright, intelligent men, eager for the opportunity to learn" (Barker, 1988). She notes:

Astonished by this revelation of the intellectual abilities and ambitions of prisoners, we offered to recruit volunteer professors to teach at Norfolk if the University would grant credits and tuition-remission scholarships. The B.U. Administration of that time was considering the proposal until the adverse publicity resulting from the STEP participants' robbery in 1970 caused a decision against it (Barker, 1990).

It was only after John R. Silber became President of Boston University that the program was initiated. Barker described how she obtained 
Silber's authorization during a meeting of the faculty executive group in which she, as head of the Student Life Committee, debated with him about his negative attitude toward student anti-war demonstrators. As he left the meeting in a state of anger, she followed him down the administration building stairs to ask him, as she had the previous administration, to authorize her recruiting professors to teach credit courses with tuition scholarships. Silber responded enthusiastically. In doing so, the volunteer professors were in the next five years able to prepare seven prison students to receive Metropolitan College's Bachelor of Liberal Studies degree, with an Interdisciplinary Studies major.

In 1977, Silber agreed that a degree program should not depend on volunteers and ever since has supported the payment of prison teachers whom he considers as semi-volunteers, since they work for very modest stipends. In 1986, while at a reception in Norfolk, he responded favorably to the request of about twenty B.U. prison graduates for a master's degree program. He asked Barker to initiate it at once, increasing the prison education budget to make it possible. In 1988, he conferred Master of Liberal Arts diplomas on the first three to earn them and continues his support of the expanded programs, which now (1991) operate at both M.C.I. Norfolk and the Bay State Correctional Center.

Dante Germanotta, founder of Curry College's Justice Education Project, became involved in a similar fashion. Germanotta, as an educator deeply concerned with issues of social justice, became actively involved in the prisons and prison education after a former prisoner visited and spoke at one of his on-campus classes in 1981. He began to include sessions with prisoners at Massachusetts Lancaster prison in the schedule of Curry's criminal justice classes. Like Barker, he discovered intelligent men who were willing to share their prison experience, but most importantly, who demonstrated an eagerness to learn. Several years later, in response to requests from prisoners, he managed to convince Curry College to enroll prisoners in accredited courses taught by volunteers from Curry's faculty (Germanotta, 1988).

Each program, founded in altruism, delivered the learning function of higher education to prisoners, and each of the founders employed language that express the hope for, if not the manifest objective of reformation. Yet the 'fascinating coincidences' that led to the development of these programs sometimes obscures the need for careful consideration of the impact they have had on the total environment of the prison.

\section{STABILIZATION AND THE SEARCH FOR THEORY}

As these programs matured, Barker and Germanotta have done much to shape the structure of higher learning in Massachusetts' prisons. At 
Norfolk prison, the University of Massachusetts, Boston offers college preparatory work and courses through the sophomore year, while Boston University offers junior and senior level courses. That model is duplicated in the relationship between the University of Massachusetts, Amherst and Mount Wachusett Community College at their sites in Gardner and Lancaster prisons. Curry College delivers a degreegranting program at MCI-Walpole. Germanotta went on to found the Massachusetts Council on Prison Education, a support organization which seeks to express the common interest and concerns of the various colleges and universities involved in the prisons and, to some extent, coordinate their activities.

Yet the most striking similarity among the higher learning programs in Massachusetts' prisons is their emphasis on the liberal arts and the humanities. It is in this common curriculum and in efforts to express its rationale that the reformative impulse of the Massachusetts' educators finds its clearest expression. For example, Boston University's program at Norfolk serves as a model of the various liberal arts curricula, which began as a reflection of Barker's academic interests, but:

'evolved,' without prior theory, to create a program which is both particular to the prison in its cognitive-moral emphasis and standard to the university in its academic requirements and criteria (Barker, 1984).

The Boston University program offers a familiar product through its adherence to the university's 'academic requirements and criteria,' but in refiguring that product's content and style to achieve a 'cognitivemoral emphasis' for prisoner/students, it reveals its essentially reformative aims.

Barker readily acknowledges the influence upon her expressions of curriculum rationale of Steven Duguid, a Canadian educator who has attempted to advance theory supporting higher learning's reformative aims (Duguid, 1979; 1980; 1981a; 1981b; 1987). Like Duguid (1981c), Barker begins with the refutation of the medical model which dominated correctional programming up to the end of the rehabilitative era in the early 1970s. That model assumed criminal behavior to be the product of a perspective which regarded the offender as a diseased person who needed to be 'cured' and, as such, became an object, a thing to be examined, studied, and acted upon (Barker, 1985). In contrast, educational models emphasizing cognitive-moral developments assume that prisoners are responsible individuals who exercise free will, albeit poorly. Barker notes that the educational model proceeds from the assumption that criminal offenders, whatever their special problems and circumstances, do not differ from mankind in general respect to their possession of reason, imagination, appreciation of beauty, respect for honor and integrity, and the ability to make morally self- 
determining choices on the basis of their perceptions of reality (1986: 9).

If, as Duguid posits, "most prisoners are simply deficient in certain analytic problem-solving skills, interpersonal and social skills and in ethical/moral development" (Duguid, 1981c:143), the task confronting prison education is to provide the offender with opportunities for cognitive and moral development. Cognitive development will guide the offender to a new thought structure which alters his perceptions of other individuals and the social world, while moral development will alter the way in which he interprets his perceptions and, ultimately, how he behaves (Barker, 1986 and 1988; Duguid, 1981b). "The very process of achieving this," Barker notes, "constitutes an education befitting free men" (1986).

Both Barker and Duguid aver that reformation can be accomplished through a liberal arts curriculum that fosters skills enabling the offender to identify and solve the many types of problems encountered in the course of life in a manner which reflects both a knowledge of alternative approaches to issues and an awareness of the consequences of considered resolutions.

A liberal arts education ... fulfils such a role because it prefigures that day with challenges and options which prison life generally life does not provide (Barker, 1986:12).

If the goal is to improve moral reasoning, the liberal arts makes that goal reachable. It presents compelling circumstances which transcend the spatial and temporal boundaries of personal existence and focus instead upon the resolution of complex issues and problems. Further, it furnishes opportunities to develop critical thinking skills in place of rigid, personal dogma. Cognitive moral development is accomplished by enabling the student to perceive in ways that credit multiple perspectives, moral development is accomplished by enabling the student to interpret alternatives in ways that reflect mature consideration of competing consequences, and reformation is achieved when higher cognitive and moral functioning lead to the acquisition of new values that will guide the actual behavior of the offender (Barker, 1984; Duguid, 1981a and 1987).

There is little coincidence in the 'fit' between Duguid's theory and higher learning's practice in Massachusetts' prisons. Barker, Duguid, Germanotta, and others involved in Massachusetts prison education are friends and colleagues. They are frequently in contact and have collaborated in the preparation of lectures and presentations for a variety of regional, national, and international conferences concerning the status and future of prison education. 


\section{INTER-SYSTEM RELATIONS}

The realization of higher learning's reformative aims is dependent upon the interplay of the stated intentions and systematic qualities of corrections. Although the relationship between higher learning and corrections at the policy level has lately been characterized by cooperation, this has not always been the case nor does it extend through all levels of the correctional apparatus. The 'atmosphere' in which the programs operate and in which prisoners/students study and learn is the product of variable realities within the correctional hierarchy. Three of these, the policy level, the classification and treatment level, and line officers will be considered here.

\section{The Policy Level}

Friction between higher learning and correction is often attributed to conflicting aims. "While corrections," one source notes, "is designed for custody and control, the purpose of education is freedom, growth, and self-actualization" (Corcoran, 1985:53). Higher learning and corrections are most compatible, however, at the policy level where aims are formulated. Senior correctional administrators speaking the language of 'justice models' emphasize the functions of custody and control, but must also allow 'rehabilitative' opportunities for those prisoners who truly desire them. Indeed, the existence of competing aims is essential to justice models of correction. Germanotta notes:

[A] justice model is a model which theoretically makes no assumption that anyone ought to be addressed at all, but lets them self-select and finally some end up doing what they want to do. But you warehouse the rest (Germanotta, 1988).

This model, in short, cannot be legitimated without the opportunity to make choices, an opportunity provided by such outsiders as Boston University and Curry College's liberal arts programs. In fact, this curriculum is ideal, since it is grounded in the principle of freedom to choose, the individual's moral duty to make responsible, acceptable choices.

Nonetheless, the advantages of liberal arts education as rehabilitation has its limitations. Correctional personnel at the policy-making level, sensitive to public criticism that offenders might benefit from their crimes,' have refrained from offering avocation, educational, or vocational programs which have currency beyond the prison. While correctional administrators have expressed support for higher learning in the prison, they have generally opposed the granting of credits for courses, and the current commissioner of corrections and the state's governor (in 1991) have expressed opposition to degree programs within the prisons. Only after a successful prisoner-initiated court 
challenge, for example, was Curry College able to offer its degree program in Walpole.

\section{The Classification and Treatment Level}

Almost all non-security activities within the prison fall within the bounds of the classification and treatment level. Treatment personnel responsible for the provision of rehabilitative opportunities are generally receptive to higher learning for the obvious reason that the emphasis corrections places on security is reflected in resource allocation, leaving treatment personnel without the funding required to develop and implement meaningful programs. Higher learning programs resolve their fiscal problems. In many instances the university programs are among the largest and most expensive 'treatment' efforts within the prison, yet some expenses are covered by grants and the university without costs to corrections.

Classification is another matter. There is a nexus between treatment and classification which threatens the integrity of the learning process. Classification personnel take pains to inform prisoners that participation in programs such as education will have a favorable impact on classification status and, ultimately the likelihood of parole. Belief in the validity of this claim is encouraged by higher learning. For example:

In view of the good records of the no-longer-incarcerated participants in the B.U. program, its professors and coordinator feel no hesitation in recommending that the educational commitment and work of their prison students be given consideration in connection with applications for release (Boston University, 1988).

Classification 'contracts' binding the prisoner's classification status to participation in certain programs often specify educational criteria and further reinforce the 'compulsory' nature of participation. The threats this creates for the integrity of the learning process are numerous. Education is transformed into coercive action in which the exercise of voluntary participation may become impossible. The emphasis of students is shifted from the experience of learning to the pursuit of good grades, credits, and degrees into fulfilling requirements that will satisfy the classification process. The desire for learning or personal growth becomes subservient to a powerful unethical reward system. Many seats at all levels in prison education programs are occupied by men and women who neither desire nor intend to learn. They want to satisfy the expectations of classification officers and this is exacerbated by state laws providing for reductions-in-sentence via 'good time' earned for participation in the programs.

Student motivations are not the only potential casualty of this 
'hidden curriculum.' Most faculty members are aware that academic performance may influence a prisoner's future and some demonstrate a reluctance to grade based on performance. This may explain the actions of one professor who announced, early in the semester, that all students would receive an ' $A$ ' regardless of their performance. Some of his students were elated at the promise of an unearned grade, but others felt 'cheated' and expressed disillusionment. Success has little value when failure is impossible.

\section{Line Officers}

The prison is a technology which seeks to actualize the social perception that the offender is "lesser in the scheme of social types" (Garfinkel, 1956). It accomplishes this by stripping the individual of all socially approved statuses. The prisoner is mortified, de-socialized, and subjected to interpersonal terrorism and personal contamination in a moral atmosphere which is authoritarian and dehumanizing. The prison teaches the offender that he or she is incompetent, irresponsible, and without worth (Goffman, 1961). These systematic features of incarceration are maintained through the routine behavior of lower-level line officers who have historically opposed higher learning's presence in the prison. The good prisoner, in the ideology of the line staff officer, 'knows his place.' He does not seek meaningful change in his life. He works at a menial job, passes his time watching television, and 'talks sports.' The 'good prisoner' has accepted his fundamental lack of worth and is resigned to a life without social or economic status, during and after incarceration.

Prisoners who strive to better themselves through higher learning are viewed as 'problematic' and 'arrogant' and are accused of 'conning the system' by pretending to be something they are not. They are subjected to increased personal harassment and other forms of interpersonal terrorism. Instructors and program co-ordinators of the advanced educational programs do not escape harassment. The programs are accused of politicizing inmates. Faculty may have been subjected to humiliating strip searches and forced to endure long and needless delays in entering the prison. Class materials are arbitrarily declared 'contraband.' Anyone associated with higher learning in the prisons whether as a prisoner/student or faculty member has experienced the hostility and resentment of lower-level personnel. Familiarity with higher learning programs by line staff eases but does not eradicate opposition at this level. Even at Norfolk prison, where higher learning has been active for two decades, line staff officers continue to express opposition to the alien presence. 


\section{CONCLUSIONS}

The 'dedicated volunteers' who introduced college-level instruction into the Massachusetts' prison system hoped it would have a 'liberalizing effect' on prisoners and the prison environment. They genuinely sought to enrich the lives of a small number of prisoners who exhibited a thirst for learning. The colleges and universities which subsequently entered the prison system in force may have possessed a variety of motivations, but they were clearly guided by an unabashed faith in the power of education to achieve the goal of reformation that had eluded corrections for almost two centuries.

Higher learning's ability to develop and implement education programs in Massachusetts' prisons has exceeded the expectations of early program founders. The growth and stability which it now enjoys appears largely attributable to the penal philosophy which emerged subsequent to the collapse of the rehabilitative ideal. Higher learning's reformative aspirations strongly suggest a deliberate or quasi-deliberate transfer of the reformative aim of incarceration, but convincing evidence that higher education can intersect criminal behavior remains elusive.

The current emphasis upon liberal arts and the humanities has its origins in the personal preferences of program founders. The universality of liberal arts curricula among the various higher learning programs is justified by its ability to promote cognitive and moral development, but no empirical evidence convincingly supports this claim and there is no substantial link between cognitive ability and criminality. Further, evidence of a reformative effect upon offenders is scant and unconvincing. In light of these facts, higher learning's reluctance to deliver more technical or skill-based curricula may be merely a matter of habit and politics.

The principal dilemmas higher learning must confront is its unintended collusion with the penal apparatus, which arises from the coincidence of interests it shares with the Massachusetts' Department of Corrections. Entry into the prison milieu transforms the fundamental character of education. Its basic premises and values are undermined by the coercive environment in which it operates. Whether intended or not, its presence within the prison immerses it in the scheme of bifurcation that lies at the heart of justice models of incarceration. As prison higher education programs become increasingly integrated with corrections, there is a danger that they are becoming complicit in a process that has historically done little but degrade and defile.

Many prisoners, myself included, owe much to those who made it their business to bring higher education into our lives. To suggest, however, that they have yet to grapple with the many significant 
implications of their practice within the prisons is not to express a lack of gratitude. If prison higher education hopes to endure as a meaningful force in reshaping the lives of men and women who live in confinement, it must begin to examine both the historic and contemporary coincidence of interests that not only facilitated its beginnings but will also shape its future.

\section{ENDNOTES}

1. The literature calls attention to a multiplicity of objectives among them increased educational levels (Seashore, et al., 1976) and meeting such psycho-social needs as self-esteem (Pendleton, 1981; Gehring, 1088). But these may be considered of secondary importance because they are presumed to be instrumental to achieving the rehabilitation of the offender. As one writer notes: "The theoretical assumption behind all the education programs developed, however, is that if becoming a criminal is a learning process, the remaking of useful citizens is more the task of education than it is the outcome of custody or punishment" (Corcoran, 1981:49). The literature is replete with such statements, suggesting that the reform or rehabilitation of the offender has priority among the objectives of higher learning in the prisons.

Further evidence regarding objectives is expressed in that portion of the literature relating to the nature of program assessments and evaluations. Some assessments and evaluations have concluded that no correlation exists between participation in higher learning programs and the rate at which offenders subsequently returned to prison (Blumstein and Cohen, 1974; Seashore, et al., 1976); others have determined that a significant correlation in fact exists (Chase and Dickover, 1983; Thorpe, MacDonald, and Bala, 1984; Duguid, 1981; Blackburn, 1981). Though the findings are inconsistent, in every case program efficacy is measured in relation to recidivism.

2. Those interviewed include: Elizabeth Barker, Professor Emeritus at Boston University, founder and director of that institution's Prison Education Program; Kit Bryant, Director of the University of Massachusetts, Boston's Higher Education in Prison Program; and Dante Germanotta, founder and director of Curry College's Justice Education Program.

3. Factors beyond the prison also contributed to the timing of higher learning's entry. As one program director noted: "Among the most important appears to be: (1) the overall growth of the educational system, more schools, more community colleges, more universities with an expanded commitment to community interests and public service; (2) the number of technical jobs had increased, calling for a more technical workforce; and (3) government, including public universities, perceived its role as an involved actor in the solution of social problems" (Bryant, 1984).

4. Since we are discussing the nexus between theory and praxis in the 'real' contexts which were exclusively male, 'he/him' is appropriate and nonsexist. 


\section{REFERENCES}

Adams, S. 1968. College Level Instruction in U.S. Prison: An Explanatory Survey. New York: Ford Foundation

American Friends Service Committee. 1971. Struggle for Justice. New York: Hill and Wang

Angle, T. 1982. 'The Development of Education Programs in American Adult Prisons and Juvenile Reformatories During the Nineteenth Century.' Joumal of Correctional Education, 33, September: 35-39

Barker, E. 1988. Interviews conducted on November 7 at Boston University in Boston, Massachusetts and on November 19 at MCI-Lancaster in Lancaster

- 1985. 'The Paradox of Punishment in Light of the Anticipatory Role of Abolitionism.' A paper presented to the International Conference on Prison Abolition, Amsterdam, June 25

- 1984. 'The Liberal Arts in the Correctional Setting.' An unpublished paper presented to the Forty-first International Conference, Cincinnati, Ohio (July).

Beckerman, A., and L. Fontana. 1987. 'Value Orientations of Prison and Non-Prison Social Work Students.' Jourmal of Offender Counselling Seroices and Rehabilitation, 11 (2): 21-32

Blackburn, F.S. 1981. 'The Relationship Between Recidivism and Participation in a Community College Program for Incarcerated Offenders.' Joumal of Correctional Education, 32, (September): 23-25

Blumstein, A., and J. Cohen. 1974. An Evaluation of a College Level Program in a Maximum-Security Prison. Pittsburg: Carnegie-Mellon University

Boston University. 1988. 'The Boston University Program in the State Prison.' A press release issued by the President's Office, May

Brodt, S., and J.D. Hewitt. 1984. 'Teaching Cons About Crime and Justice: Experiment with Non-Traditional Students in a Non-Traditional Setting.' Journal of Correctional Education 35, (March): 15-19

Bryant, K. 1988. Interview conducted on November 9 at MCI-Lancaster in Lancaster, Massachusetts

Bryant, K. (1984) An unpublished Master's thesis (Boston: University of Massachusetts).

Chase, L.J., and R.C. Dickover. 1983. 'University Education at Folsom Prison: An Evaluation.' Joumal of Correctional Education, 34, (September): $92-95$

Corcoran, F. 1985. 'Pedagogy in Prison.' Communication Education, 34 (1): 49-58

Duguid, S. 1987. 'Prison Education: A Case for the Liberal Arts.' Jourmal of Correctional Education, 38 (September): 108-112

- 1981a. 'Moral Development, Justice and Democracy in the Prison,' L. Morin, ed., On Prison Education. Ottawa: Ministry of Supply and Services

- 1981b. 'Rehabilitation Through Education: A Canadian Model.' L. Morin, ed., On Prison Education. Ottawa: Ministry of Supply and Services

- 1980. 'Three Components of Prison Education.' Crime and Social Justice, 15, (Winter): 30-38

- 1979. 'History and Moral Development in Correctional Education.' Canadian Journal of Education, 4 (4)

Enocksson, K. 1980. 'Correctional Programs: A Review of the Value of Educational Training in Penal Institutions.' Journal of Offender Counselling Services, and Rehabilitation, 5, (Fall): 35-39

Foucault, M. 1977. Discipline and Punish:The Birth of the Prison. New York: Pantheon

Garfinkel, H. 1956. 'The Conditions of Successful Degradation Ceremonies.' American Journal of Sociology, 61: 420-424

Gehring, T. 1988. 'The Connection Between Democracy and Cognitive Process in Correctional Education.' Journal of Correctional Education, 39, (June): 62-69

Germanotta, D. (1988). Interview conducted on November 19 at MCI-Lancaster in Lancaster, Massachusetts 
Goffman, E. 1961. Asylums: Essays on the Social Situation of Mental Patients and Other Inmates. Chicago: Aldine

Homant, R.J. 1984. 'On the Role of Values in Correctional Education.' Joumal of Correctional Education, 5, (March): 8-12

Hruska, T.J. 1981. Morality and the Study of Literature in Correctional Education.' Journal of Correctional Education, 35, (March): 23-28

Kiser, G.C. 1987. 'Teaching College Courses to Inmates.' Jourmal of Correctional Education, 38, (September): 102-116

Linden, R., et al. 1982. 'An Evaluation of a Prison Education Program.' Canadian Journal of Criminology, 12, (May): 123-140

Marsh, J.J. 1973. 'Higher Education in American Prisons.' Crime and Delinquency, October

Menninger, K. 1969. The Crime of Punishment. New York: Viking

Morris, D. 1966. 'The University's Role in Prison Education.' Nebraska Law Review, 45 (3): $542-564$

Osperg, T.M. 1977. 'Further Issues in Prison Teaching: A Response to Dodd.' Teaching of Psychology, 14 (4): 233-235

Parlett, T.A. 1981. 'The Benefits of Advanced Education in Prisons.' L Morin, ed., On Prison Education. Ottawa: Ministry of Supply and Services

Pendleton, E.P. 1988). 'Student-Centered Instruction: A Prison College Model for Building Self-Esteem.' Joumal of Correctional Education, 39, (June): 82-84

Pisciotta, W. 1983. 'Scientific Reform: The “New Penology” at Elmira, 1876-1900.' Crime and Delinquency, October: 613-628

Reagan, M., and D.M. Stoughton. 1976. School Behind Bars: A Descriptive Overview of Correctional Education. Methuchen: The Scarecrow Press.

Rothman, D.J. (1980. Conscience and Convenience: The Asylum and its Alternatives in Progressive America. Boston: Little, Brown and Company

Roberts, R. 1971. Sourcebook on Prison Education. Springfield: C.C. Thomas.

Seashore, M.J., et al. 1976. Prisoner Education: Project Newgate and Other College Programs. New York: Praeger

Thorpe, T., et al. (1984. 'Follow-up Study of Offenders Who Earn College Degrees While Incarcerated in New York State.' Jourmal of Correctional Education, 35, (September): $86-88$ 